\title{
TESTIRANJE BIOLOŠKE UČINKOVITOSTI FEROMONA I KLOPKI ZA ULOV MEDITERANSKOG POTKORNJAKA Orthotomicus erosus (Coleoptera, Curculionidae)
}

\section{TESTING OF BIOLOGICAL EFFECTIVENESS OF PHEROMONES AND TRAPS FOR CATCH OF MEDITERRANEAN BARK BEETLE Orthotomicus erosus (Coleoptera, Curculionidae)}

Milan PERNEK', Marta KOVAČ ${ }^{1 *}$, Nikola LACKOVIĆ2

\section{SAŽETAK}

U šumama alepskog bora na hrvatskom Mediteranu u 2017. godini pojavio se mediteranski potkornjak (Orthotomicus erosus) u gustoćama populacije koje do tada nisu zabilježene te se nikada prije nije smatrao značajnim štetnikom na tom području. Naglo povećanje populacije potkornjaka prirodni neprijatelji nisu u stanju pratiti, a ishod je naglo povećanje sušaca. U sklopu mjera zaštite za suzbijanje mediteranskog potkornjaka u 2018. godini u Hrvatskoj su postavljene feromonske klopke u svrhu monitoringa. Iako postoji više mogućnosti primjene različitih vrsta klopki i feromonskih pripravaka za mediteranski potkornjak, do sada nije istraženo koja je razlika u ulovima različitih vrsta klopki niti koliko su selektivne. U 2019. godini na području Park šume Marjan (Split) na 196 ha šumske površine postavljeno je 40 feromonskih klopki. Uspoređeni su parovi feromonskih pripravaka Pheroprax i Erosowit, sustav triju klopki Triplet sa običnom naletno barijernom klopkom te modificirana klopka sa mokrim ulovom i obična naletno barijerna klopka. Osim prosječnog broja ulova u feromonskim klopkama posebna pozornost dana je selektivnosti. Od predatora u klopama su značajnije su nađene dvije vrste, Tanasimus formicarius i Temnochila caerulea, s tim da je T. formicarius u odnosu na T. caerulea bio u zanemarivim količinama. Rezultati ukazuju kako pripravak Erosowit u odnosu na Pheroprax pokazuje značajno veće ulove, te je značajno selektivniji. Pheroprax ima vrlo visoke ulove predatora T. caerulea te se ne preporuča za praktičnu primjenu. Triplet je u odnosu na običnu naletno barijernu klopku pokazao tek neznatno bolje ulove, ali i nešto bolju selektivnost. Triplet nije pokazao očekivani učinak s obzirom na količinu ulova koja je bila nešto viša u odnosu na običnu klopku, ali ne značajnije kako bi se preporučila njihova primjena. Mokra varijanta klopke pokazala se lošom, jer ne donosi signifikantno veće ulove od obične naletno barijerne klopke, a dvostruko manje je selektivna. S obzirom na dodatne troškove (adaptacija klopke, tekućina koja se mora mijenjati, sporije sakupljanje) ovaj tip klopke nije preporučljiv za primjenu. Usporedbom ukupnih prosječnih ulova mediteranskog potkornjaka 2018. i 2019. godine utvrđeno je da je broj potkornjaka u 2019. gotovo 5 puta manji u odnosu na 2018.

KLJUČNE RIJEČI: Pinus halepensis, Erosowit, Pheroprax, Taemnochila caerulea, Thanasimus formicarius, klimatske promjene.

\footnotetext{
1 Dr. sc. Milan Pernek, Marta Kovač, mag. ing. silv., Hrvatski šumarski institut, Zavod za zaštitu šuma i lovno gospodarenje, Cvjetno naselje 41, 10450 Jastrebarsko ${ }^{2}$ Dr. sc.Nikola Lacković, Antuna Mihanovića 3, 10450 Jastrebarsko

*Corresponding: Marta Kovač; martam@sumins.hr
} 


\section{UVOD}

\section{INTRODUCTION}

Ulančavanje nepovoljnih čimbenika kao što su klimatske promjene povezane sa monokulturom, te sekundaran napad potkornjaka, uzrokom su početnog sušenja alepskih borova (Pinus halepensis Mill.) u Dalmaciji krajem 2016. To je dovelo do početka gradacije mediteranskog potkornjaka, Orthotomicus erosus Wollaston (Coleoptera: Curculionidae: Scolytinae) u 2017. godini (Pernek 2018, Pernek i sur. 2019). Ova vrsta potkornjaka može u određenim uvjetima prijeći u primarne štetnike te početi napadati i potpuno zdrava stabla, što je poznato kod nekih vrsta potkornjaka (Wermelinger 2002). U mediteranskom području tome posebice pogoduje aridifikacija, budući da se poboljšavaju uvjeti za preživljavanje, reprodukciju, voltinizam i prostorno širenje potkornjaka (Battisti i Larson 2016). Prirodni neprijatelji nisu u stanju pratiti naglo povećanje populacije mediteranskog potkornjaka, stoga je rezultat naglo povećanje suhih stabala. Ova do tada nezabilježena pojava na hrvatskom Mediteranu pojavila se u cijeloj Dalmaciji južno od Zadra sa blažim ili jačim intenzitetom, ovisno o lokaciji. Mediteranski potkornjak se od tada gleda kao značajan štetnik na tome području (Pernek i sur. 2019), a tome posebice pogoduju ambijentalne promjene (IPCC 2014), u kojima mediteranski potkornjak nalazi uvjete za veću reprodukciju i razvijanje više generacija godišnje (Pernek i sur. 2019). U sklopu mjera zaštite za suzbijanje mediteranskog potkornjaka u 2018. godini u Hrvatskoj su na brojnim lokacijama postavljene feromonske klopke u svrhu monitoringa. Primjena feromona u zaštiti šuma spada u grupu biotehničkih metoda koje se koriste spoznajama iz područja ekofiziologije i etologije kukaca, odnosno njihovim načinom reagiranja na fizikalne i kemijske podražaje. Primjenom sintetski proizvedenih tvari nastoji se imitirati kemijski podražaj, odnosno imitirati prirodne feromone koje kukci sami produciraju, a u svrhu odbijanja ili privlačenja drugih jedinki iste vrste (agregacija) (Bakke i sur. 1977). Njihova primjena vrlo rijetko rezultira trenutnim smanjenjem neke štetne populacije (Pernek i Lacković 2011). Međutim, shvaćanje mehanizma komunikacije u biocenozi potkornjaka može biti važno u primjeni zaštitnih mjera. Razlike u feromonskoj komunikaciji postoje između geografskih područja, a isto je primijećeno kod primjene sintetskih feromona (Grosman i sur. 1997), stoga testiranje feromona ima praktični značaj za gospodarenje šumama.

Primjena feromonske klopke uzrokuje određene promjene u populacijama neciljanih organizama, stoga treba voditi računa o selektivnosti (Pernek i Lacković 2011). Poznato je kako feromonske komponente kairomonski privlače prirodne neprijatelje potkornjaka (Schroeder 2003, Pajares i sur. 2004), zbog čega je važno dobro proučiti i valorizirati utjecaj feromona u ekosustavu u širem smislu. Velik broj slučajnih nepoželjnih ulova u gustoj mreži klopki sigurno bi mogao imati nepovoljne posljedice po ekološki balans. Primjerice, u svrhu bolje selektivnosti danas se rabe samo crno obojene klopke (Niemeyer 1985). Komponente koje imaju učinak kairomona na prirodne neprijatelje potkornjaka daju signal koji daje obavijest o prisutnosti hrane, te dolazi do ulova većeg ili manjeg broja nepoželjnih vrsta. To za feromonsku klopu može biti pokazatelj kvalitete s obzirom da bi komponente trebale biti izbalansirane da otpuštaju točno određenu količinu u vremenu (ratio rate) i da su što više selektivne. Testiranjem pojedinih komponenti Pheropraxa otkriveno je kako na predatora Thanasimus formicarius L. (Coleoptera, Cleridae) djeluje komponenta ipsenol i ipsdienol, a manje (S)-cis-verbenol (Pavlin 1991). Slično bi moglo biti sa vrlo učestalom predatorskom vrstom, Temnochila caerulea Olivier. (Coleoptera, Trogositidae). Privlačenje ovih važnih predatora u velikom broju u feromonske klopke može predstavljati problem za zaštitu šuma (Etxebeste i sur. 2012).

Vrlo je važno znati kako feromonska klopka nije univerzalno sredstvo kojim se rješava problem potkornjaka, već je ona dio integrirane zaštite koja kombinira sve raspoložive metode zaštite u cilju sprječavanja ekonomskih šteta uz što manje poremećaja prirodnih neprijatelja, što manje onečišćenje okoliša te što niži utrošak energije (Maceljski i sur. 1983). Davanje prevelike važnosti feromonskoj klopki kao profilaktičkoj ili represivnoj mjeri može u nekim slučajevima biti kontraproduktivno, jer nepravilno i bezrazložno postavljanje klopki može izazvati neželjene posljedice, kao što je privlačenje potkornjaka pojava dodatnih žarišta.

U sklopu Izvještajno prognoznih poslova (IPP) u Hrvatskoj u 2018. godini postavljen je veći broj feromonskih klopki za ulov mediteranskog potkornjaka diljem Dalmacije (www.stetnici.hr). Ulovi su se jako međusobno razlikovali s obzirom na lokaciju postavljanja, ali je zapažen iznimno velik broj jedinki na nekim lokacijama koji je dosegao i do 30.000 jedinki tjedno (Pernek 2018). Takvi neuobičajeno veliki ulovi otvorili su nova pitanja o mogućnostima primjene feromonske klopke kao dio integrirane zaštite, odnosno njihovog korištenja u izlovu, što znači primjenu kao kurativne mjere zaštite, a ne samo za monitoring. Budući da se za mediteranskog potkornjaka do sada nisu postavljale feromonske klopke nije poznato da li postoji razlika u ulovima niti je poznato koliko su selektivne odnosno privlače li prirodne neprijatelje. Odgovori na ta pitanja čine osnovu u planiranju zaštite šuma i neophodna su za šumarskog stručnjaka na terenu. Stoga je cilj ovog istraživanja usporedba različitih vrsta feromonskih pripravaka, klopki i sistema klopki i utvrđivanje koja kombinacija daje najbolje rezultate, te temeljem dobivenih rezulata davanje preporuke za gospodarenje šumama u uvjetima gradacije mediteranskog potkornjaka. Također se temeljem ulova u 


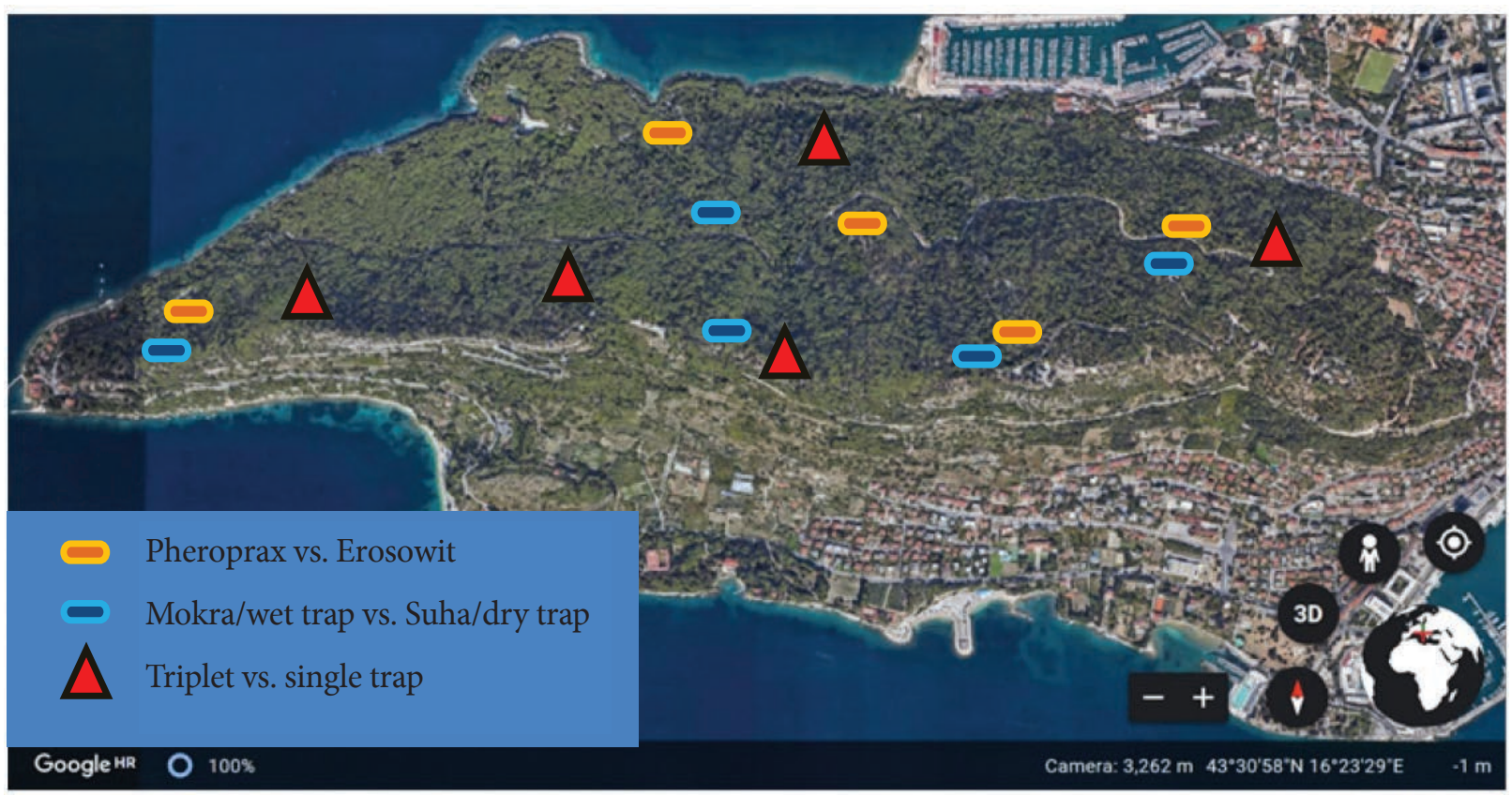

Slika 1. Lokacije klopki u Park šumi Marjan 2019. godine

Figure 1 Locations of traps in Park Forest Marjan in 2019

feromonskim klopkama u 2019. te usporedbom s ulovima iz 2018. procijennjuje populacijska dinamika mediteranskog potkornjaka.

\section{MATERIJALI I METODE RADA MATERIALS AND METHODS}

Pokusi sa feromonskim klopkama započeli su u proljeće 2019. godine, kada je postavljeno ukupno 40 feromonskih klopki na lokaciji Park šuma Marjan. Ukupna površina park šume je 300.29 ha, a smještena je na marjanskom poluotoku, krajnje zapadnom dijelu splitskog poluotoka. Pod vegetacijom se nalazi 196.24 ha većim dijelom na sjevernoj strani poluotoka, a čine ga uglavnom šume alepskog bora. Velik broj klopki zahtijevao je planiranje dovoljnog broja feromonskih pripravaka (200 komada), koji su se morali propisno skladištiti u frižiderima. Svi navedeni materijali nabavljeni su prije početka izlaženja prezimljujućeg mediteranskog potkornjaka. Podaci sakupljeni u 2018. godini (Pernek 2018) poslužili su za usporedbu i procjenu stanja napada potkornjaka u 2019. godini i evaluaciju feromonske klopke u zaštitne svrhe.

Prilikom odabira mikrolokacije uzeto je u obzir da klopke budu postavljene minimalno $20 \mathrm{~m}$ od prvih zdravih stabala borova. Klopke su u svrhu usporedbe postavljene u parovima (Slika 1):

\section{POKUS 1}

Klopka: jednostavna naletno barijerna klopka (NBK); feromonski pripravak: Pheroprax (5) u usporedbi Erosowit (5);

\section{POKUS 2}

Feromonski pripravak: Erosowit; klopka: Triplet (5x3=15) u usporedbi sa jednostavnom NBK (5);

POKUS 3

Feromonski pripravak: Pheroprax ; klopka: jednostavna NBK mokra (5) u usporedbi sa suhom klopkom (5)

Razmak između klopki u paru bio je oko $20 \mathrm{~m}$.

Prvi pokusni par (POKUS 1) činilo je 5 NBK klopki za koje je korišten feromonski pripravak Pheroprax (BASF) (Slika 2) koji se obično koristi za praćenje populacije smrekovog pisara (Ips typographus L.). Opisan je ranije u Izraelu kao feromon koji služi za ulov mediteranskog potkornjaka (Mendel 1988). Drugih 5 feromonskih pripravaka su činili Erosowit (Witasek) (Slika 3) koji je sintetiziran u svrhu praćenja populacije mediteranskog potkornjaka, a korišten je u 2018. godini (Pernek 2018).

U drugom pokusnom paru (POKUS 2) uspoređivana je razlika u ulovima tzv. Triplet klopke, odnosno 3 NBK povezane u jedan sustav (Slika 6) na ukupno 5 lokacija s jednostavnom NBK.

U trećem pokusnom paru (POKUS 3) korištena je metoda „suhog" ulova (5 klopki) što je zapravo jednostavna NBK, i „mokrog“ ulova (Slika 7 i Slika 8) (5 klopki). Za sve klopke korišten je feromonski pripravak Pheroprax. Ova usporedba dvaju tipa klopki testirana je iz razloga kako bi se istražilo da li potkornjaci izlaze van iz lovne posude, te tako smanjuju stvaran rezultat ulova (Pernek i sur. 2003). U klopke s „mokrim“ ulovom u lovnu posudu je stavljena tekućina (mješavina vode i deterdžentskog sredstva). Teku- 


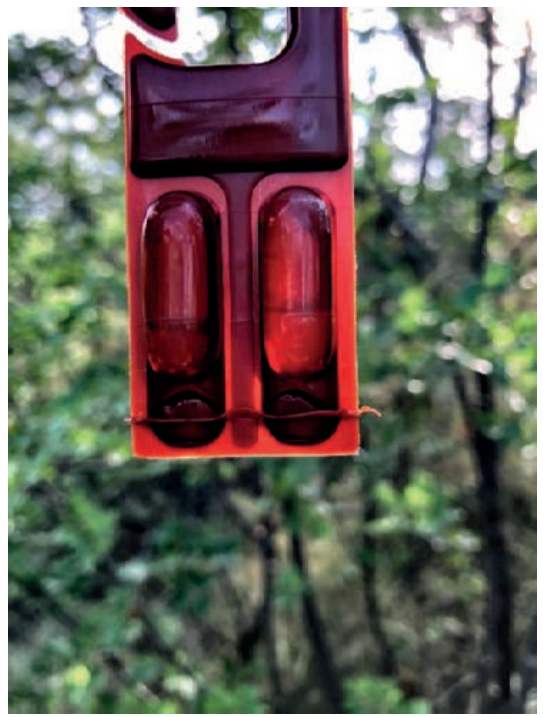

Slika 2. Feromonski pripravak Pheroprax Figure 2 Pheromone preparation Pheroprax

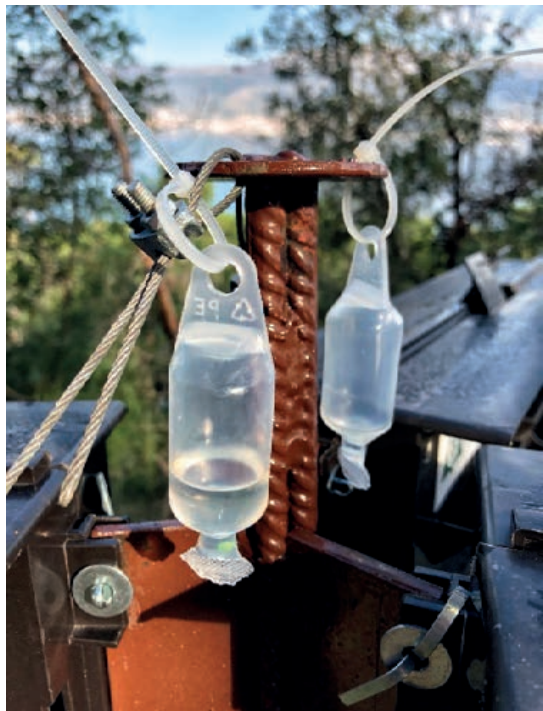

Figure 3 Pheromone preparation Erosowit Slika 3. Feromonski pripravak Erosowit

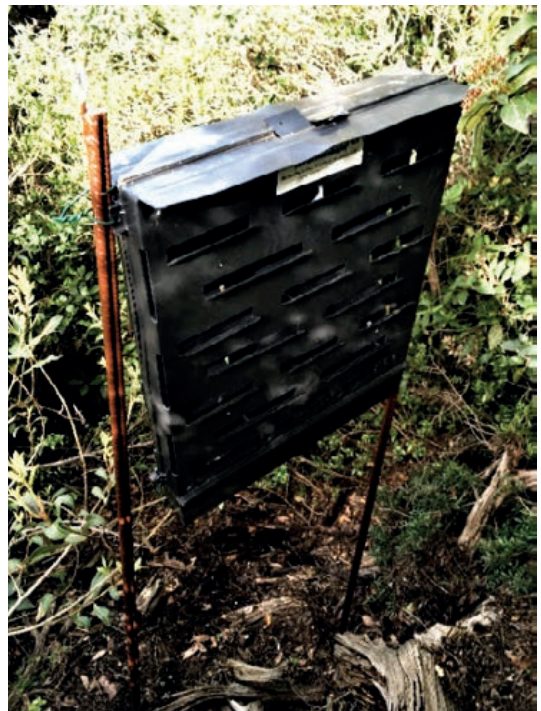

Slika 4. Suha feromonska barijerno naletna klopka (Theysohn)

Figure 4 Dry flight barrier pheromone trap (Theysohn)

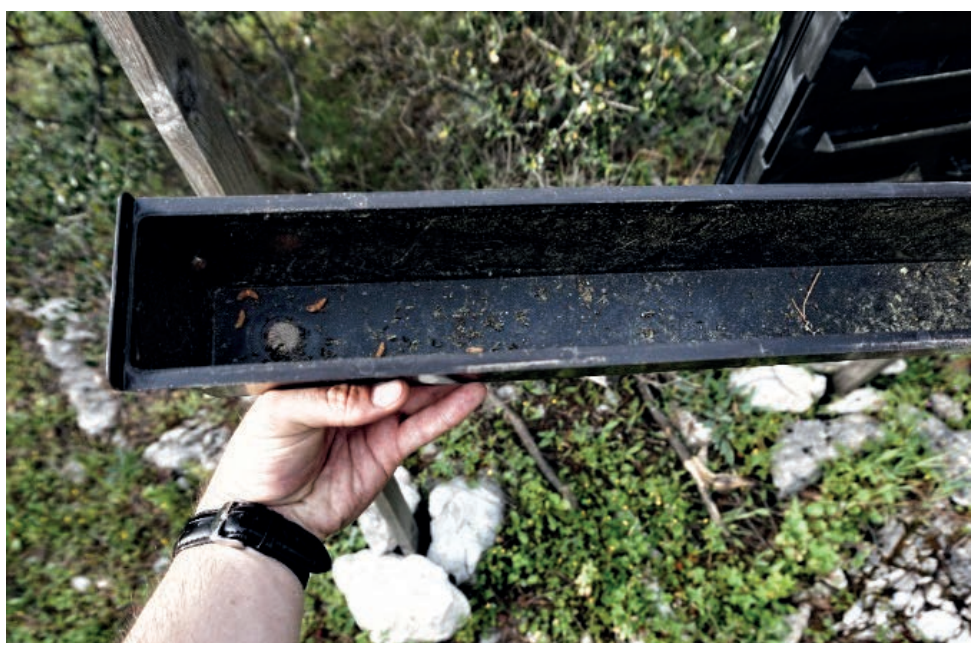

Slika 5. Suha lovna posudica feromonske klopke

Figure 5 Dry catching vessel of pheromone trap

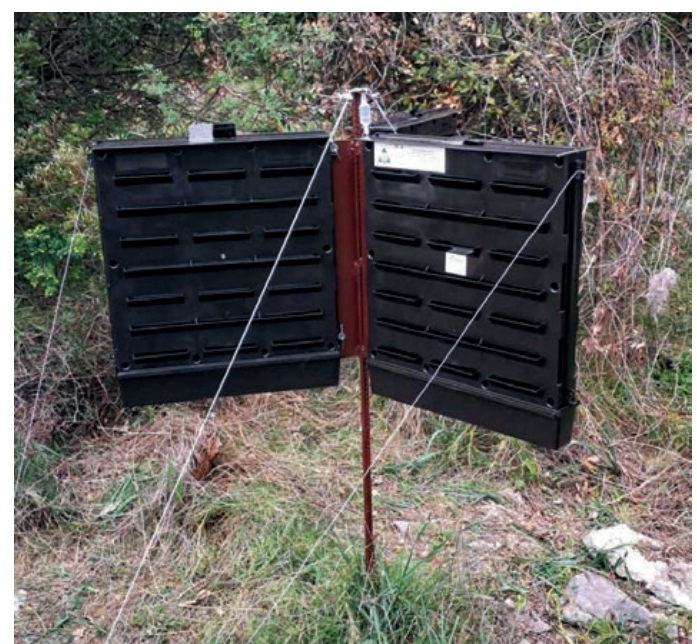

Slika 6. Naletno barijerne klopke u sustavu Triplet

Figure 6 Flight barrier pheromone traps in Triplet system

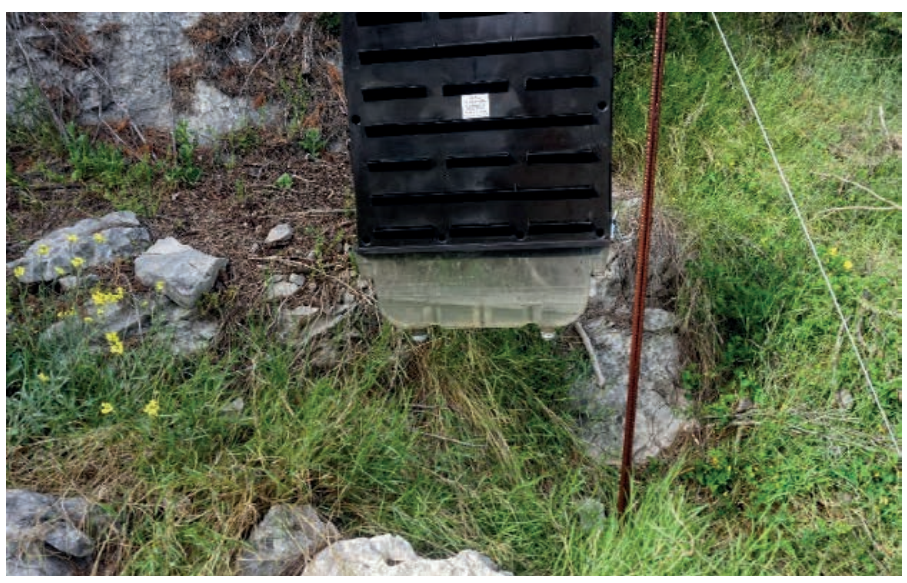

Slika 7. Mokra feromonska barijerno naletna klopka Figure 7. Wet flight barrier pheromone trap

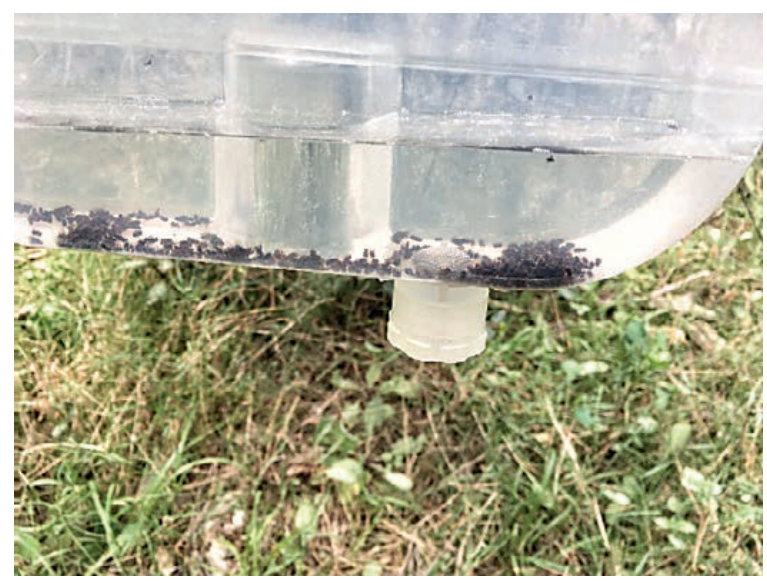

Slika 8. Mokra lovna posudica feromonske klopke

Figure 8. Wet catching vessel of pheromone trap 
Tablica 1. Vrste i broj feromonskih pripravaka i klopki postavljenih na terenu

Table 1 Types and number of pheromone preparations and traps set in the field

\begin{tabular}{lcc}
\multicolumn{1}{c}{ Vrsta } & $\begin{array}{c}\text { Broj klopki po } \\
\text { stajalištu }\end{array}$ & $\begin{array}{c}\text { Broj klopki u } \\
\text { pokusu }\end{array}$ \\
$\begin{array}{l}\text { BARIJERNO NALETNA KLOPKA } \\
\text { EROSOWIT (E) }\end{array}$ & 1 & 5 \\
$\begin{array}{l}\text { BARIJERNO NALETNA KLOPKA } \\
\text { EROSOWIT (T) }\end{array}$ & 1 & 5 \\
$\begin{array}{l}\text { BARIJERNO NALETNA KLOPKA } \\
\text { PHEROPRAX (P) }\end{array}$ & 1 & 5 \\
$\begin{array}{l}\text { TRIPLET BARIJERNO NALETNIH } \\
\text { KLOPKI EROSOWIT (TP) }\end{array}$ & 3 & 15 \\
$\begin{array}{l}\text { BARIJERNO NALETNA KLOPKA } \\
\text { PHEROPRAX-suha (S) }\end{array}$ & 1 & 5 \\
$\begin{array}{l}\text { BARIJERNO NALETNA KLOPKA } \\
\text { PHEROPRAX-mokra (M) } \\
\text { ukUPnO }\end{array}$ & 1 & 5 \\
\end{tabular}

Tablica 2. Frekvencija broja dana između dva sakupljanja ulova iz feromonskih klopki

Table 2 Frequency of the number of days between two catches collection from pheromone traps

\begin{tabular}{cc} 
Broj dana & Frekvencija \\
5 & $1(4 \%)$ \\
6 & $1(4 \%)$ \\
7 & $12(46 \%)$ \\
8 & $3(11 \%)$ \\
9 & $2(8 \%)$ \\
10 & $2(8 \%)$ \\
11 & 0 \\
12 & 0 \\
13 & 0 \\
14 & $4(15 \%)$ \\
22 & $1(4 \%)$ \\
\hline
\end{tabular}

ćina se mijenjala u razdoblju u vremenskim razmacima kada se sakupljao ulov.

Sve vrste klopki korištene u pokusima su navedene u Tablici 1, a uhvaćene jedinke u klopkama stavljene su prilikom sakupljanja u etanol (70 \%) i spremljene u bočice, radi očuvanja uzoraka i daljnje laboratorijske analize.

Sve klopke i feromoni postavljeni su 23.3.2019. godine, a prvo sakupljanje obavljeno je 30.3.2019. Ukupno je obavljeno 26 sakupljanja kroz godinu, sve do 7.11.2019. nakon čega nije više bilo ulova.

Nakon što su postavljene sve klopke na za to posebno dizajniranim željeznim stupovima koji su zabijani u tlo, postavljeni su feromonski pripravci sukladno predviđenom planu (Slika 1.). Potkornjaci ulovljeni u klopke sakupljali su se u plastične posudice s poklopcem na kojem se ispisala lokacija, vrsta klopke i datum, kako bi se u kasnijoj laboratorijskoj obradi ispravno zabilježilo.
Klopke su se praznile u pravilu svakih 7 dana (46\%), ali su iznimke bile u nekoliko navrata. Najmanji razmak bio je 5 dana, a najveći razmak dogodio se u rujnu/listopadu (13.9.7.10.) kada je između sakupljanja ulova bilo 3 tjedna (Tablica 2). Ipak najveći broj podataka nalazi se između 5 i 10 dana (81\%) (Tablica 2), što je s obzirom na relevantnost podataka zadovoljavajuće.

Analiza ulova iz feromonskih klopki napravljena je u laboratoriju za entomološka ispitivanja Hrvatskog šumarskog instituta (Jastrebarsko). Kukci su prvo razvrstavani po taksonomskim kategorijama i osušeni kako bi se olakšalo brojanje. Po taksonomskim kategorijama kukci su identificirani prema dostupnim morfološkim ključevima (za potkornjake - Pfeffer 1995). Brojanje razvrstanih ulova odrađeno je ručno.

Druga važna metoda za utvrđivanja broja potkornjaka u uzorku je razvijena u okviru ovog projekta. Potkornjaci su držani u 70\% etanolu do zasićenja. Izdvojeni su svi veći kukci npr. strizibube, jednakokrilci i prirodni neprijatelji $T$. caerulea i T. formicarius. Isti su izdvojeni u posebne petrijeve posudice te ručno izbrojeni.

Sadržaj kutijica, nakon što su izdvojeni neciljani ulovi, je prosipan kroz sito veličine oko $1 \mathrm{~mm}$ te je odmah premješten u petrijevu posudicu i vagan analitičkom vagom Sartorius, BD ED 100 (ATL 224-I) točnosti 0,0001 g i to za svaku posudicu, odnosno datum i poziciju klopke posebno.

Kako bi se evaluirala točnost vaganja i odredio broj potkornjaka 50 kutijica je izdvojeno po principu slučajnosti te su vagani, a zatim su isti i ručno izbrojeni te uspoređivani s brojem dobivenim vaganjem. T-testom je dokazana točnost navedene metode te se podaci mogu smatrati vjerodostojnim.

Vaganjem je utvrđeno kako je u 1g oko 153 alkoholom zasićenih potkornjaka. Vaganje je obavljeno uvijek kada je bilo više od 200 potkornjaka u uzorku. Kada ih nije bilo 200, brojanje je obavljeno ručno.

Istraživanje efikasnosti kombinacija metoda postavljanja klopki i feromonskih pripravaka provedeno je tijekom 2019. godine s ciljem dolaska do odgovora na niz pitanja vezanih za optimalnu primjenu pripravaka i klopki. Postavljanjem više paralelnih pokusa radi usporedbi vrsta i dizajna klopki, traženi su odgovori na sljedeća pitanja:

i) postoji li razlika u feromonskim pripravcima Erosowit (E) i Pheroprax (P);

ii) postoji li razlika u ulovima s obzirom na sustav postavljanja klopaka (Triplet (TP) usporedno sa NBK (T));

iii) postoji li razlika u ulovima s obzirom na način zarobljavanja potkornjaka u posudama („,mokra“ (M) vs. „suha“ (S)); 
Tablica 3. Deskriptiva i rezultati parametarskih testova između ulova sa feromonskim pripravkom Pheroprax (P) i Erosowit.(E) Testovi sa statistički značajnim rezultatom su istaknuti.

Table 3 Descriptive and parameter test results between catches with the pheromone preparation Pheroprax (P) and Erosowit (E). Tests with statistically significant results are highlighted.

$\begin{array}{ccccccccc}\begin{array}{l}\text { Varijabla } \\ \text { Variable }\end{array} & \begin{array}{c}\text { Broj opažanja } \\ \text { Observations }\end{array} & \text { Minimum } & \text { Maximum } & \text { Mean } & \text { Std. deviation } & \begin{array}{c}\text { t-test } \\ \text { [df] } \\ p\end{array} & \begin{array}{c}\text { F-test } \\ \text { [df] } \\ p\end{array} \\ \text { P } & 130 & 0,000 & 5142,000 & 443,185 & 795,826 & -2,282 & 0,299 \\ {[129,129]} & {[129,129]} & <, 012 & <0,0001\end{array}$

iv) postoji li razlika u selektivnosti (Erosowit vs. Pheroprax; te "mokra“ (M) usporedno sa „suhom" (S));

v) postoji li razlika u ulovima klopki između godine sakupljanja 2018. i 2019. godine.

Utvrđivanje signifikantnosti razlika u iznosima ulova između parova kombinacija upotrjebljenih metoda i feromonskih pripravaka provedeno je parametarskim statističkim testovima odstupanja srednjih vrijednosti i rasipanja podataka.

\section{REZULTATI}

\section{RESULTS}

Razlika u ulovima između pripravaka Erosowit

i Pheroprax - Catch differences between Erosowit and Pheroprax

Usporedbom ulova dviju vrsta feromonskih pripravaka ukupno je u 5 klopki ulovljeno 57.614 jedinki mediteranskog potkornjaka $(36,4 \%)$ sa feromonom Pheroprax, te 100.762 (63,6\%) jedinki sa Erosowitom. Utvrđeno je kako postoji signifikantna razlika u količini ulova, te su se ulovi razlikovali kroz cijelu godinu (Tablica 3, Slika 9).

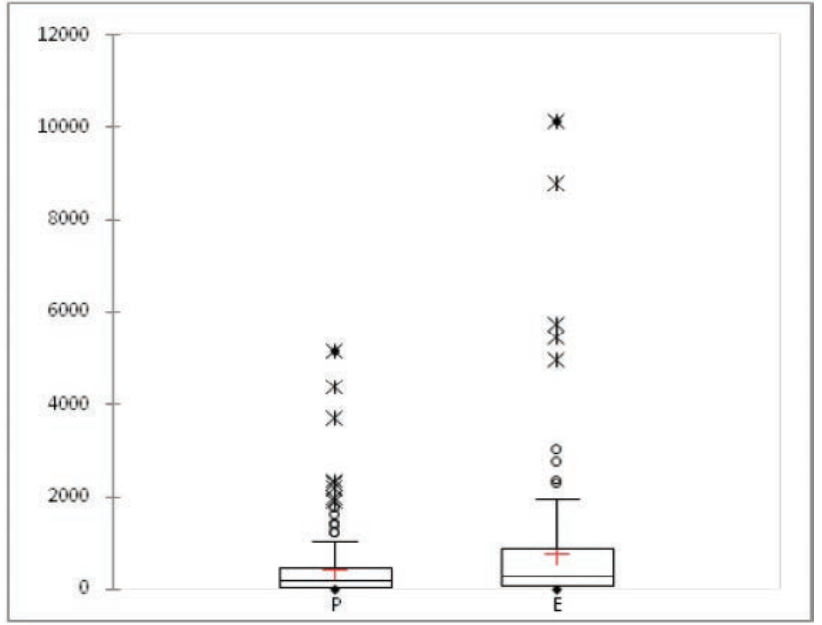

Slika 9. Box-Whiskers dijagram distribucije veličina ulova sa feromonskim pripravkom Pheroprax (P) i Erosowit (E). Parametarskim testom utvrđene su statistički značajno veće srednje vrijednosti ulova i varijabilnost u veličini ulova sa feromonom Erosowit.

Figure 9 Box-Whiskers catch size distribution diagram for pheromone preparation Pheroprax (P) and Erosowit (E). The parametric test found statistically significantly higher mean values of the catch and variability in size of the catch with the Erosowit pheromone.

Najveći ulov Pheropraxom zabilježen je 3.8. kada je prosječno ulovljeno 1.678 jedinki mediteranskog potkornjaka

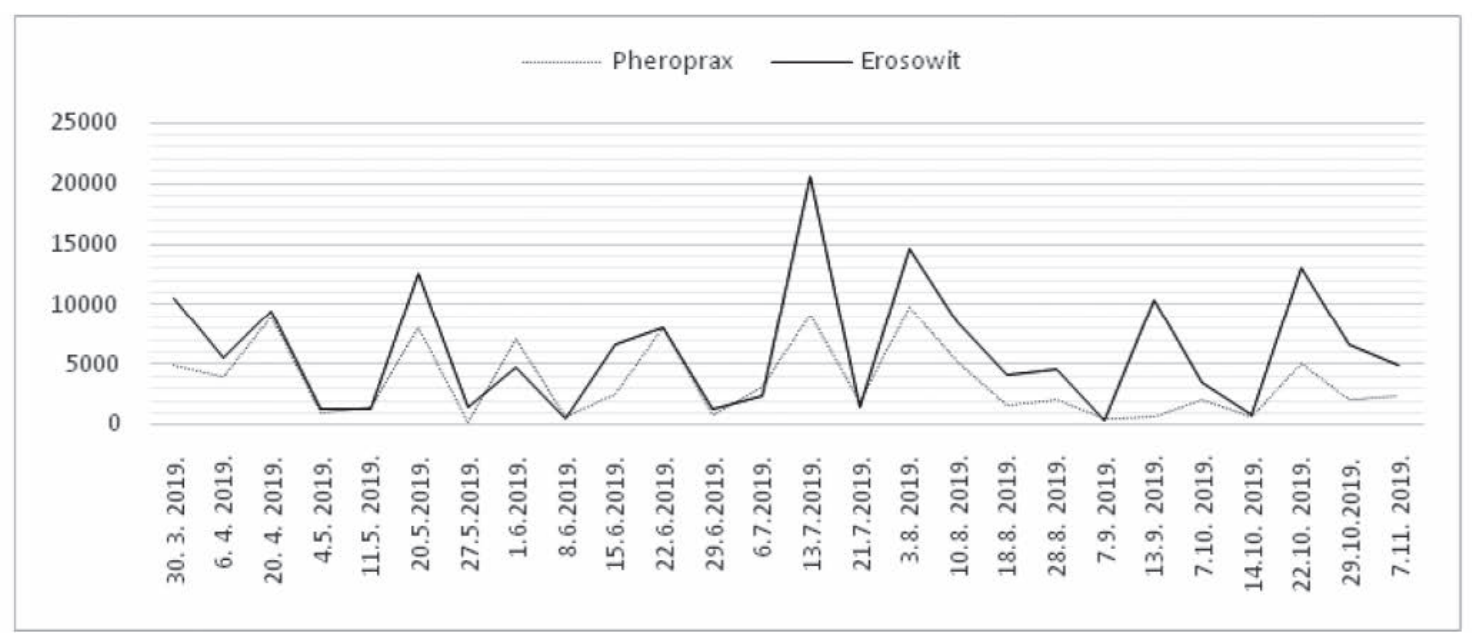

Slika 10. Usporedba prosječnih ulova potkornjaka Orthotomicus erosus u klopkama sa pripravkom Pheroprax i Erosowit.

Figure 10 Comparison of the average catch of bark beetle Orthotomicus erosus in traps with preparation Pheroprax and Erosowit 
Tablica 4. Deskriptiva i rezultati parametarskih testova između sustava Triplet (TP) i pojedinačneNBK (T). Testovi sa statistički značajnim rezultatom su istaknuti.

Table 4 Descriptive and parameter test results between Triplet system (TP) and single flight barrier trap (T). Tests with statistically significant results are highlighted.

\begin{tabular}{|c|c|c|c|c|c|c|c|}
\hline $\begin{array}{l}\text { Varijabla } \\
\text { Variable }\end{array}$ & $\begin{array}{l}\text { Broj opažanja } \\
\text { Observations }\end{array}$ & Minimum & Maximum & Mean & Std. deviation & $\begin{array}{c}\text { t-test } \\
\text { [df] } \\
p\end{array}$ & $\begin{array}{c}\text { F-test } \\
\text { [df] } \\
P\end{array}$ \\
\hline TP & 130 & 0,000 & 9610,000 & 856,592 & 1540,067 & $\begin{array}{c}0,805 \\
{[129,129]}\end{array}$ & $\begin{array}{c}1,498 \\
{[129,129]}\end{array}$ \\
\hline $\mathrm{T}$ & 130 & 0,000 & 7632,000 & 716,123 & 1258,461 & 0,421 & 0,023 \\
\hline
\end{tabular}

po klopki, dok je Erosowitom najviše ulovljeno 13.7. kada je bilo 4.294 jedinke potkornjaka po klopki (Tablica 3). Prosječno je Pheropraxom po klopki kroz čitavo razdoblje sakupljanja ulovljeno 443, a Erosowitom 775 jedinki mediteranskog potkornjaka. Najveći broj ulovljenih jedinki u jednoj Pheroprax klopki zabilježen je 22.6. kada je ulovljeno 5.142 jedinke mediteranskog potkornjaka, a najveći broj u jednoj Erosowit klopki zabilježen je 29.6. kada je ulovljeno 10.134 jedinke mediteranskog potkornjaka (Slika 10).

\section{Razlika u ulovima između sustava klopki Triplet i pojedinačne naletno barijerne klopke - Catch differences between traps in system Triplet and single trap}

Usporedbom ulova dviju vrsta feromonskih pripravaka ukupno je u 5 klopki ulovljeno 111.357 jedinki $(54,5 \%)$ sa Triplet sustavom, te 93.096 (45,5\%) jedinki sa NBK. Srednje vrijednosti ulova između dvaju modela postavljanja klopki nisu se statistički značajno razlikovali, iako je model postave u triplet imao značajno veću varijabilnost u veličini ulova (Tablica 4).

Najveći ulov sustavom Triplet zabilježen je 30.3. kada je prosječno ulovljeno 3.728 jedinki mediteranskog potkor-

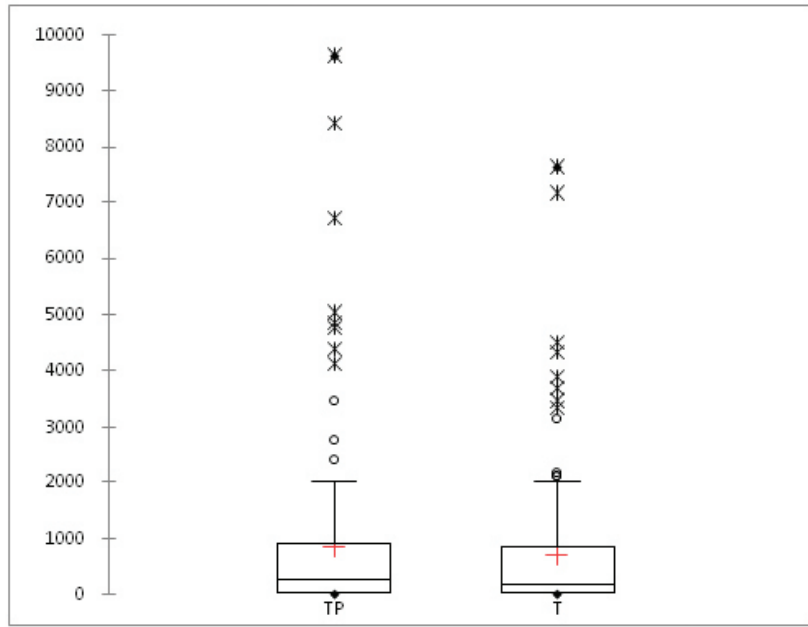

Slika 11. Box-Whiskers dijagram distribucije veličina ulova između modela postavljanja klopki u Triplet (TP) i pojedinačne NBK (T). Parametarskim testovima utvrđeno je da nema statistički značajne razlike u srednjim vrijednostima ulova dok je varijabilnost u veličini ulova značajno veća sa modelom postave u Triplet.

Figure 11 Box-Whiskers catch size distribution diagram between the trap system Triplet (TP) and single flight barrier trap (T). Parametric tests found that there is no statistically significant difference in the mean values of the catch, while variability in size of the catch was significantly higher with the trap system Triplet.

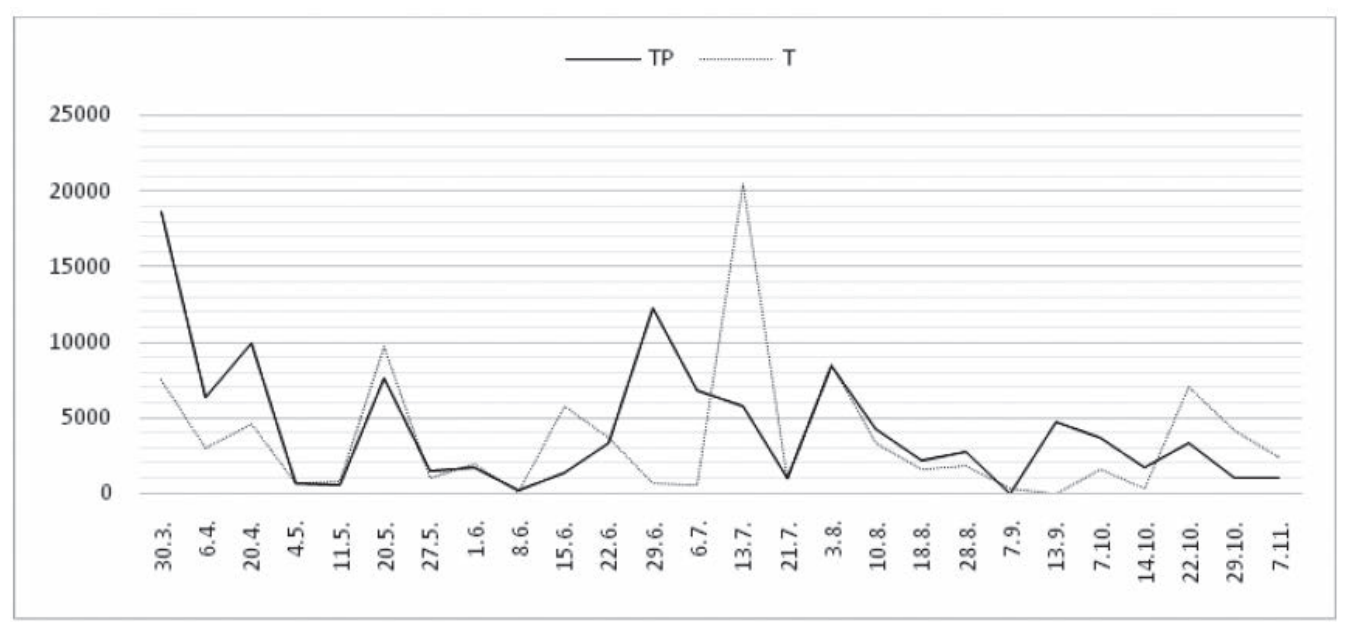

Slika 12. Usporedba prosječnih ulova potkornjaka Orthotomicus erosus u tri sustava feromonskih klopki; TP-Triplet, T- pojedinačna klopka Figure 12 Comparison of the average catch of bark beetle Orthotomicus erosus in two pheromone trap systems; TP- Triplet, T- single trap 
Tablica 5. Deskriptiva i rezultati parametarskih testova između sustava klopke sa posudom za mokri ulov i suhi ulov. Testovi sa statistički značajnim rezultatom su istaknuti.

Table 5 Descriptive and parameter test results between trap system with vessel for wet catch and dry catch. Tests with statistically significant results are highlighted.

$\begin{array}{cccccccc}\begin{array}{c}\text { Varijabla } \\ \text { Variable }\end{array} & \begin{array}{c}\text { Broj opažanja } \\ \text { Observations }\end{array} & \text { Minimum } & \text { Maximum } & \text { Mean } & \text { Std. deviation } & \begin{array}{c}\text { t-test } \\ \text { [df] } \\ p\end{array} & \begin{array}{c}\text { F-test } \\ \text { [df] } \\ P\end{array} \\ \text { M } & 130 & 0,000 & 8144,000 & 522,600 & 1057,496 & 1,166 & 1,991 \\ \text { S } & 130 & 0,000 & 3772,000 & 390,062 & 749,515 & 0,245 \quad & <0,0001\end{array}$

njaka po klopki (Tablica 3). Prosječno je Tripletom po klopki kroz čitavo razdoblje sakupljanja ulovljeno 856 jedinki. Najveći broj ulovljenih jedinki u jednoj Triplet klopki zabilježen je 29.6. kada je ulovljeno 9.610 jedinki mediteranskog potkornjaka (Slika 11).

\section{Razlika u ulovima "mokre“ i "suhe“ klopke - Catch differences between "wet" and "dry" traps}

Usporedbom ulova dviju vrsta feromonskih pripravaka ukupno je u 5 klopki ulovljeno 67.938 jedinki $(57,3 \%)$ sa mokrom NBK, te 50.708 jedinki $(42,7 \%)$ sa suhom NBK. Srednje vrijednosti ulova između dvaju modela postavljanja klopki nisu se statistički značajno razlikovali, iako je model postave sa posudom za mokri ulov imao značajno veću varijabilnost u veličini ulova (Tablica 5).

Najveći ulov mokrom NBK zabilježen je 13.7. kada je prosječno ulovljeno 2.815 jedinki mediteranskog potkornjaka po klopki, dok je suhom NBK najveći ulov bio 3.8. kada je bilo 3.772 jedinke potkornjaka po klopki (Tablica 3). Prosječno je mokrom NBK po klopki kroz čitavo razdoblje sakupljanja ulovljeno 522, a suhom NBK 390 jedinki mediteranskog potkornjaka (Slika 14).

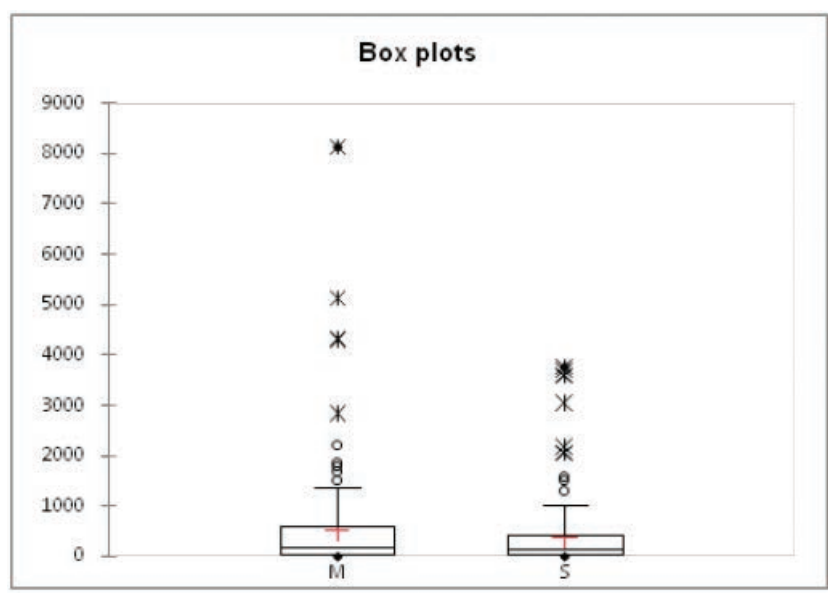

Slika 13. Box-Whiskers dijagram distribucije veličina ulova između modela postavljanja klopki sa posudom za mokri ulov (M) i posudom za suhi ulov (S). Parametarskim testovima utvrđeno je da nema statistički značajne razlike u srednjim vrijednostima ulova dok je varijabilnost u veličini ulova značajno veća sa posudom za mokri ulov.

Figure 13 Box-Whiskers catch size distribution diagram between the trap system with wet catch (M) and dry catch (S). Parametric tests found that there is no statistically significant difference in the mean values of the catch, while variability in size of the catch was significantly higher with the wet catching vessel.

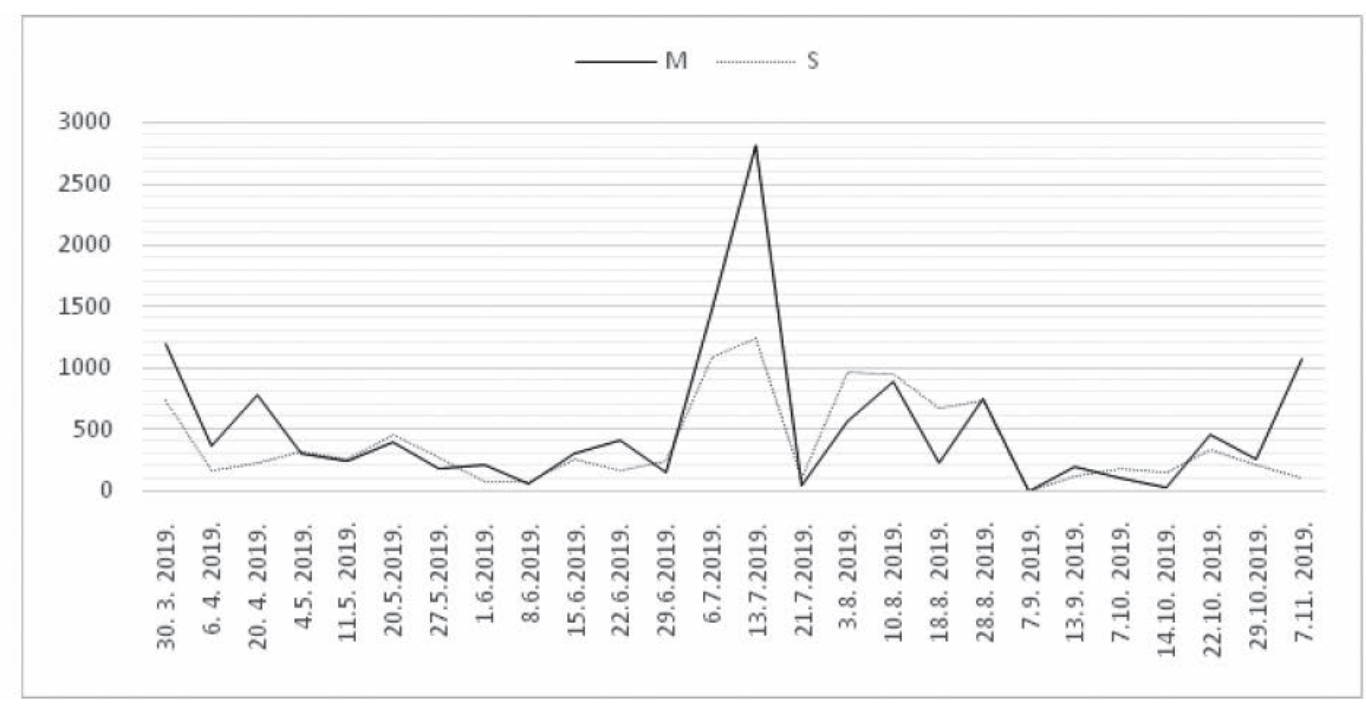

Slika 14. Usporedba prosječnih ulova potkornjaka Orthotomicus erosus u mokroj (M) odnosno suhoj (S) naletno barijernoj klopki. Figure 14 Comparison of the average catch of bark beetle Orthotomicus erosus in wet (M) and dry (S) flight barrier trap 


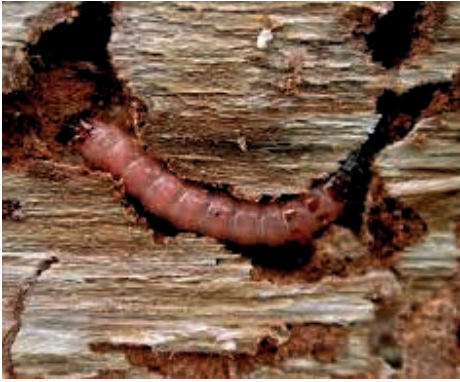

Slika 15. Larva predatorske vrste Thanasimus formicarius

Figure 15 Larva of the predatory species Thanasimus formicarius

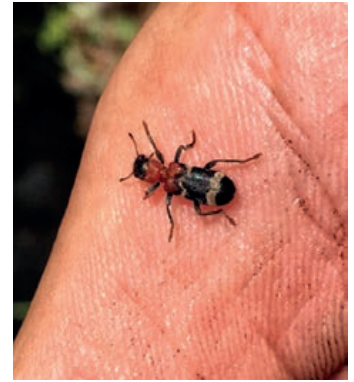

Slika 16. Imago predatorske vrste Thanasimus formicarius Figure 16 Imago of the predatory species Thanasimus formicarius

\section{Selektivnost feromonskih klopki - Selectivity of pheromone traps}

$\mathrm{U}$ ovom istraživanju referirali smo se na predatore T. formicarius, koji se hrani potkornjacima kao imago i kao ličinka (Slika 15 i 16), te na T. caerulea (Slika 17 i 18), najvažniju vrstu koja se najčešće nalazi u feromonskim klopkama.
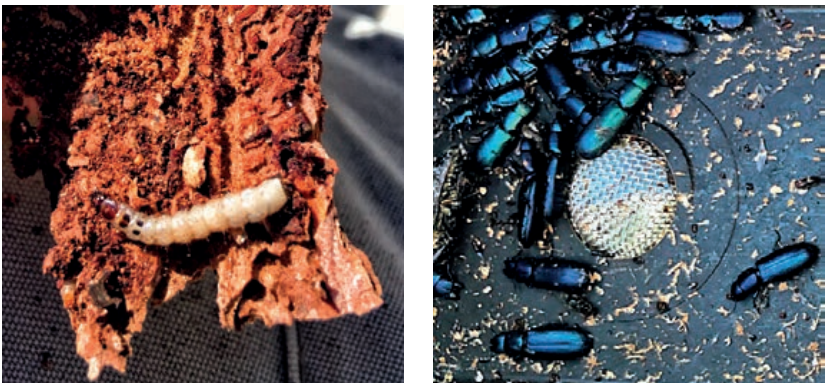

Slika 17. Larva predatorske vrste Temnochila caerulea

Figure 17 Larva of the predatory species Temnochila caerulea
Slika 18. Imaga predatorske vrste Temnochila caerulea

Figure 18 Imago of the predatory species Temnochila caerulea

Oba nabrojana predatora vrlo su česta i nalaze se u ulovima feromonskih klopki. Važan predator Aulonium ruficorne Olivier (Coleoptera, Zopheridae) iznenađujuće je bila u vrlo malim količinama u ulovima. Poznavanje predatora važno je kako bi se prilikom sakupljanja ulova izbacili natrag u prirodu, te tako imali pozitivan učinak na smanjenje populacija potkornjaka.

Tablica 6. Razlike u ulovima predatora Temnochila caerulea i Thanasimus formicarius između različitih tipova feromonskih klopki Table 6 Differences in catches of Temnochila caerulea and Thanasimus formicarius predators between different types of pheromone traps

\begin{tabular}{|c|c|c|c|}
\hline Klopka/feromon & $\begin{array}{c}\text { Broj ulova Thanasimus formicarius } \\
\text { Number of Thanasimus formicarius } \\
\text { catches }\end{array}$ & $\begin{array}{c}\text { Broj ulova Temnochila caerulea } \\
\text { Number of Temnochila caerulea catches }\end{array}$ & $\begin{array}{l}\text { Prosječan ulov predatora po klopki i } \\
\text { sakupljanju } \\
\text { Average catch of predators pro trap and } \\
\text { collection }\end{array}$ \\
\hline $\begin{array}{c}\text { NBK } \\
\text { PHEROPRAX }\end{array}$ & 27 & 2.985 & 23 \\
\hline $\begin{array}{c}\text { NBK } \\
\text { EROSOWIT }\end{array}$ & 37 & 1.546 & 11 \\
\hline $\begin{array}{l}\text { TRIPLET } \\
\text { EROSOWIT }\end{array}$ & & 1200 & 9 \\
\hline $\begin{array}{l}\text { NBK MOKRA } \\
\text { PHEROPRAX }\end{array}$ & & 522 & 15 \\
\hline
\end{tabular}

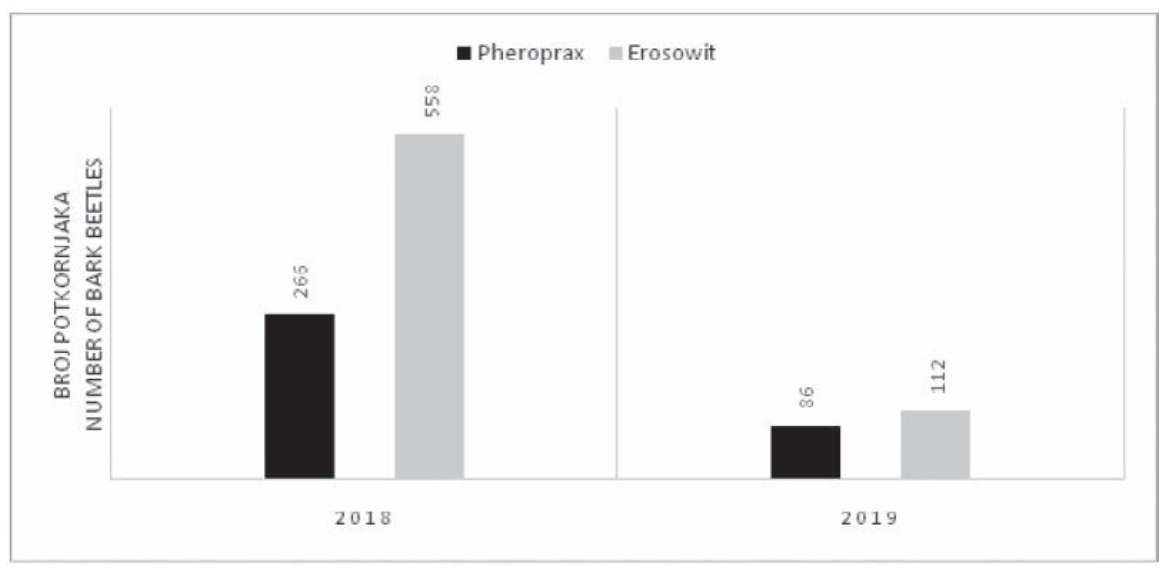

Slika 19. Ukupni prosječni ulovi jedinki Orthotomicus erosus u feromonskim klopkama u 2018. i 2019. godini (od 30.3. do 6.7.) Figure 19 Total average of catches of Orthotomicus erosus in pheromone traps in 2018 and 2019 (from 30.3. to 6.7.) 


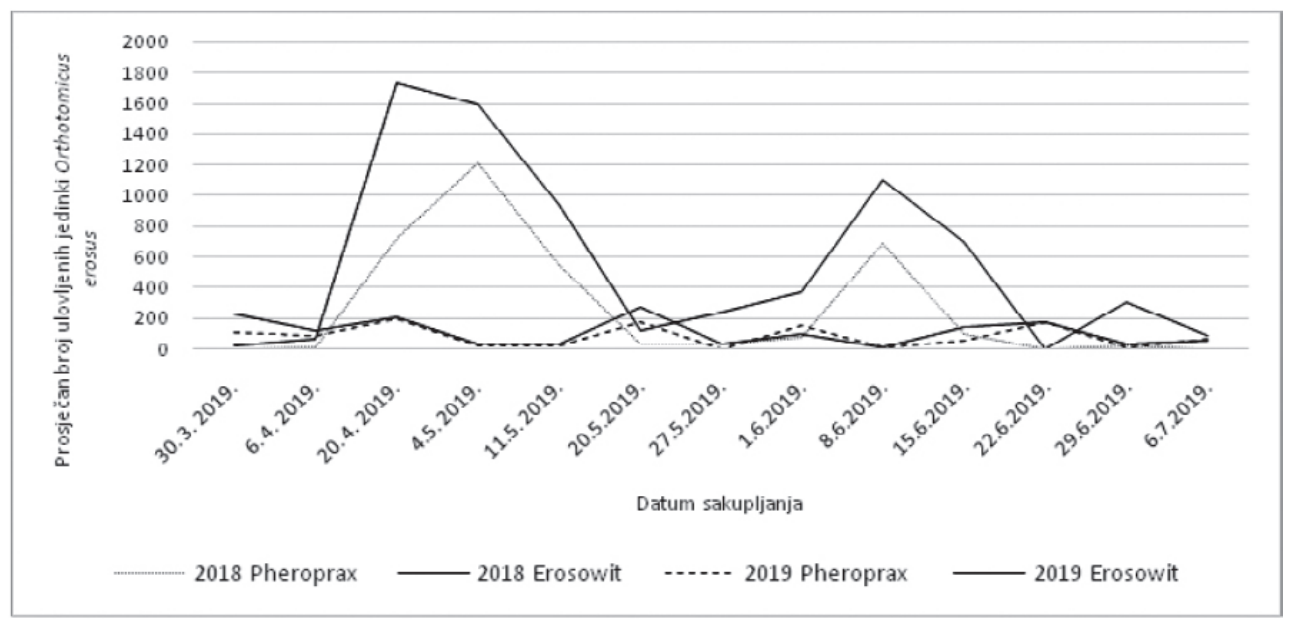

Slika 20. Prosječni ulovi potkornjaka Orthotomicus erosus u feromonskim klopkama kroz razdoblje lovljenja u 2018. i 2019 godini (od 30.3. do 6.7.) Figure 20 Average catches of bark beetle Orthotomicus erosus in pheromone traps through the hunting period in 2018 and 2019 (from 30.3. to 6.7.)

Dok se T. formicarius javio u ulovima u feromonskim klopkama u zanemarivim brojkama, vrsta $T$. caerulea bila je relativno česta (Tablica 6). U klopkama sa feromonima Pheroprax i Erosowit ukupno ulovljeno 64 jedinki T. formicarius, dok je jedinki T.caerulea bilo 4.531. Predator koji je obično čest u asocijaciji sa mediteranskim potkornjakom $A$. ruficorne (Mendel 1990, Sarikaya i Ibis 2016) iznimno je rijetko nađen u ulovima.

\section{Razlika u ulovima 2018. i 2019. godine - Difference in catches in 2018 and 2019}

Kako za 2018. godinu postoje samo podaci od 30.3. do 6.7. to je period u kojem je napravljena usporedba ulova. Uspoređene su pozicije klopke koje su bile iste i u 2018. i 2019.: 5 feromona Erosowit i 5 Pheroprax. Model klopke bio je jednostavna NBK. Sukladno rezultatu došlo je do značajnog pada broja ulova mediteranskog potkornjaka u 2019. u odnosu na 2018. godinu (Slika 19).

Prosječni ulovi u feromonskim klopkama u 2018. godinibili su signifikantno veći u većini datuma sakupljanja, za Pheroprax 3 puta, a za Erosowit 5 puta veći (Slika 19 i Slika 20).

\section{RASPRAVA DISCUSSION}

Feromonske klopke kao dio integrirane zaštite šuma služe isključivo sustavu monitoringa te daju sliku i uvid u populacijsku dinamiku potkornjaka. Iako se količina ulova u različitim tipovima klopki može bitno međusobno razlikovati ipak se vidi stanje populacije potkornjaka, što ukazuje na to da broj jedinki u ulovima nije toliko bitan. Feromonske klopke uglavnom nemaju kurativnu funkciju (Vaupel 1991). Ipak, u ulovima se želi dobiti veći broj ciljanih ku- kaca jer se oni na taj način isključuju iz populacije. Međutim, puno je važnije kod feromonske klopke njezina selektivnost, budući da se isključivanjem predatora iz populacije onemogućuje njihov pozitivan utjecaj u prirodi (Weslien i Regnander 1992). To može ići do te krajnosti da broj predatora u ulovima bude toliko velik, da s obzirom na njihov prehrambeni potencijal radimo više štete nego koristi (Baier 1994).

Do sada korišteni feromoni i klopke za mediteranskog potkornjaka korišteni su sukladno navodima iz literature (Mendel 1988) ili iz istraživanja i osobnog iskustva stečenog u prvim godinama gradacije (Pernek 2018). Rezultati ukazuju opravdanost takvog istraživanja s obzirom na geografska područja i razlika vezanih uz to (Grosman i sur. 1997). $\mathrm{U}$ ovom istraživanju pratila se razlika u ulovima ciljanih kukaca (mediteranskog potkornjaka) i neciljanih (selektivnost na predatore) na temelju kojih se daju savjeti za budući monitoring. Postavljanje klopki na istom mjestu iz godine u godinu daje nam uvid u kretanje ili trendove populacije i daje prostora stručnjacima da ispravno i na vrijeme provode mjere zaštite. Prezentirani rezultati usporedbe feromona i klopki za ulov mediteranskog potkornjaka prvo je takvo istraživanje u Hrvatskoj koje treba dati neke odgovore šumarskim stručnjacima na terenu.

Erosowit je feromon koji se kroz gotovo čitavo razdoblje lovljenja pokazao boljim u odnosu na Pheroprax, imao veće ulove, ali je bio i bitno selektivniji. Time se taj feromon u kombinaciji s jednostavnom NBK pokazao kao najbolje rješenje za primjenu u praksi.

Što se tiče Triplet sustava od njega se treba očekivati da daje ulove veće od jednostavne NBK, budući da su troškovi postavljanja i sakupljanja puno veći od cijene samih klopki i feromona. Međutim Triplet je, iako neznatno, pokazao bolje ulove, ali i nešto bolju selektivnost. Stoga se i Triplet sustavi mogu preporučiti za primjenu. 
Nadalje, mokra varijanta klopke pokazala se lošom jer ne donosi signifikantno veće ulove, a manje je selektivna. $S$ obzirom na dodatne troškove klopke (adaptacija klopke, tekućina koja se mora mijenjati, sporije sakupljanje) ovaj tip klopke nije preporučljiv za primjenu.

\section{ZAKLJUČCI}

\section{CONCLUSIONS}

Erosowit je feromon koji pokazuje značajno bolje rezultate u ulovima i selektivnosti u odnosu na Pheroprax, te se preporuča njegova primjena.

Pheroprax nije dovojno selektivan za mediteranskog potkornjaka te se ne preporuča za praktičnu primjenu.

Triplet klopki lovi tek nešto više od obične klopke, ali je nešto selektivniji te se u određenim uvjetima može preporučiti.

Mokre klopke ne love značajno više od obične NBK, ali su manje selektivne, a uz to manipulacija s njima zahtijeva značajno više troškova. Zbog toga se njihova primjena ne preporuča.

Najbolja feromonska klopka za praktičnu primenu je jednostavna NBK sa feromonskim pripravkom Erosowit.

U odnosu na 2018. uslijedio je značajan pad ulova u feromonskim klopkama u 2019., što ukazuje na trend smanjivanja populacije mediteranskog potkornjaka.

\section{ZAHVALA}

\section{ACKNOWLEDGEMENTS}

Ovo istraživanje provedeno je u okviru projekta „Suzbijanje i monitoring mediteranskog potkornjaka u Park šumi Marjan“ financirano od JU Park šume Marjan. Zahvaljujemo se svim djelatnicima Park šume Marjan na pomoći oko provedbe projekta (naročito ravnatelju Damiru Grubšiću). Posebno hvala dugujemo prof.dr.sc. Mirku Ruščiću (Prirodoslovno-matematički fakultet Sveučilišta u Splitu) koji je sakupio većinu ulova na terenu. Zahvaljujemo se svim suradnicima iz Hrvatskog šumarskog instituta koji su doprinijeli terenskim i laboratorijskim radovima (Blaženka Ercegovac, Nikola Zorić, Ivana Mihaljević, Dubravko Perez, Zlatko Huljina, Ivan Lukić, Zvonimir Vujnović).

\section{LITERATURA}

\section{REFERENCES}

- Bakke, A., P. Froyen, L. Skattebol, 1977: Field response to a new pheromonal compound isolated from Ips typographus. Naturwissenschaften, 64: 98-99

- Battisti, A., S. Larsson, 2015: Climate change and insect distribution range, U: C. Björkman, P. Niemelä (ur.), Climate change and insect pests, 1-16, CABI Climate Change Series, 7
- Baier, P. 1994: Untersuchungen zur abundanzdynamischen Relevaz der Beifänge von Nemosoma elongatum L. (Col., Ostomidae), U: Chalcoprax beköderten Flugbarierfallen für Pityogenes chalcographus L. (Col., Scolytidae), Z. Ang. Ent., 117: 51-57

- Ben Jamaa, M.L., F. Lieutier, A. Yart, A. Jerraya, M.L. Khouja, 2007: The virulence of phytopathogenic fungi associated with the bark beetles Tomicus piniperda and Orthotomicus erosus in Tunisia, Forest Pathology, 37(1): 51-33

- Etxebeste, I., G. Álvarez, G. Pérez, J. Pajares, 2012; Field response of the six-toothed pine bark beetle, Ips sexdentatus (Col.: Curculionidae, Scolytinae), to pheromonal blend candidates. Journal of Applied Entomology, 136:431-444

- Grosmann D.M., S.M. Salon, F.W. Rowlin, R.W. Young, 1997: Geographic and gender diffrences in semiochemicals in emerging adult southern pine beetle (Coleoptera, Scolytidae). Ann. Ent. Soc of America, 90: 438-446.

- IPCC, 2014: Climate Change 2014: Synthesis Report. Contribution of Working Groups I, II and III to the Fifth Assessment Report of the Intergovernmental Panel on Climate Change [Core Writing Team, R.K. Pachauri, L.A. Meyer (ur.)], IPCC, pp 151, Geneva, Switzerland

- Maceljski, M., M. Ušćuplić, B. Cvjetković, Đ. Krnjaić, 1983: Integralna zaštita, Jugoslovensko savjetovanje o primjeni pesticida, Zbornik radova, 677-712, Neum

- Martin A., I. Etxebeste, G. Perez, G. Alvarez, E. Sanchez, J. Pajares, 2013: Modified pheromone traps help reduce bycatch of barkbeetle natural enemies, Agricultural and Forest Entomology 15(1): 86-97

- Mendel, Z., 1988: Attraction of Orthotomicus erosus and Pityogenes calcaratus to a synthetic aggregation pheromone of Ips typographus, Phytoparasitica, 16: 109-117

- Niemeyer, H., 1985: Field response of Ips typographus L. (Col., Scolytidae) to different trap structures and white versus black flight barriers, Z. Ang. Ent., 99: 44-51

- Nierhaus-Wunderwald, D., 1993: Die natürlichen Gegenspieler der Borkenkäfer, Wald und Holz, 1/93: 8-14.

- Mendel, Z., Podoler, H. and Livne, H. 1990: Interactions between Aulonium ruficorne (Coleoptera: Colydiidae) and other natural enemies of bark beetles (Coleptera: Scolytidae). Entomophaga 35, 99-105.

- Pajares, J.A., F. Ibeas, J.J. Diez, D. Gallego, 2004: Attractive responses by Monochamus galloprovincialis (Col., Cerambycidae) to host and bark beetle semiochemicals, Journal of Applied Entomology, 128(9-10): 633-638

- Pavlin, R., 1991: Problem selektivnosti sintetičnih feromonov, Zbornik lesarstva, 38: 126-160

- Pernek, M., 2000: Feromonska klopka i njihova uloga u integralnoj zaštiti šuma od smrekinih potkornjaka, Radovi, Jastrebarsko

- Pernek, M., B. Hrašovec, M. Županić, 2003: Beetle fauna captured in traps baited with Tomicus piniperda pheromone blends in a pine stand in central Croatia, U: M.L. McManus, A.M. Liebhold (ur.), Gen. Tech. Rep. NE-311, Newtown Square, PA: U.S. Department of Agriculture, Forest Service, Northeastern research Station Newton Square, Pensylvania, USA: USDA Forest Service, 87-89

- Pernek, M., 2018: Sušenje borova u Park šumi Marjan sa mjerama integrirane zaštite šuma za sprječavanje širenja i suzbijanje mediteranskog potkornjaka Orthotomicus erosus (Woll.), Elaborat, 83 str. 
- Pernek, M., N. Lacković, 2011: Uloga jelovih krivozubih potkornjaka u sušenju jele i mogućnosti primjene feromonskih klopki za njihov monitoring, Šumarski list, 13: 114-121

- Pernek, M., S. Novak-Agbaba, N. Lacković, N. Đođ, I. Lukić, S. Wirth, 2012: Uloga biotičkih čimbenika u sušenju borova $(P i-$ nus spp.) na području Sjeverne Dalmacije, Šumarski list, 7-8: 343-354

- Pernek, M., N. Lacković, I. Lukić, N. Zorić, D. Matošević, 2019: Outbreak of Orthotomicus erosus (Coleoptera, Curculionidae) on Aleppo Pine in the Mediterranean Region in Croatia, SEEFOR-South-east European forestry, 10(1): 19-27

- Pfeffer, A., 1995: Zentral- und westpaläarktische Borken- und Kernkäfer, Naturhistorisches Museum Basel, 309, Basel

- Rando, R.M., 2011: Studio de las curvas de vuelo de Ips sexdentatus y de sus principales predatores en diversos montes de la provincia de Teruel en 2008 y 2009, Universidad Politecnica de Valencia, 92 str.

- Sarikaya, O., H.M. Ibis, 2016: Predatory species of bark beetles in the pine forests of Izmir Region in Turkey with new records for Turkish fauna. Egyptian Journal of Biological Pest Control 26, 651-656.

- Schroeder, L.M., 2003: Differences in response to $\alpha$-pinene and ethanol, and flight periods between the bark beetle predators Thanasimus femoralis and T. formicarius (Col.: Cleridae), For. Ecol. Manag, 177: 301-311

- Vaupel, O., 1991: Möglichkeiten der Verminderung von Borkenkäferschäden durch die Anwendung von Pheromonfallen, U: Kolloquium über die Borkenkäfer-Gefahren nach Sturmschäden, Möglichkeiten und Grenzen einer integrierten Bekämpfung, Mitteilungen aus der Biologischen Bundesanstalt für Land- und Forstwirtschaft, 80-83

- Wermelinger, B., 2002: Development and distribution of predators and parasitoids during two consecutive years of an Ips typographus (Col., Scolytidae) infestation, J. Appl. Entomol., 126: 521-527

- Weslien, J., J. Regnander,1992: The influence of natural enemies on brood production in Ips typographus (Col., Scolytidae) with special reference to egg-laying and predation by Thanasimus formicarius (Col., Cleridae), Entomophaga, 37: 333-342

\section{SUMIMARY}

In the Aleppo pine forests at the Croatian Mediterranean in 2017, a Mediterranean bark beetle (Orthotomicus erosus) appeared in population densities that had not been recorded before and until then was not considered a significant pest in that area. Natural enemies are not able to follow a sudden increase of the bark beetle population, which results in rapid increase of drying trees. As a part of the suppression of the Mediterranean bark beetle in 2018, pheromone traps have been installed in Croatia for monitoring purposes. Although there are multiple options for applying different types of traps and pheromone preparations for the Mediterranean bark beetle, so far the differences in catches of different types of traps and their selectivity have not been investigated. In 2019, 40 pheromone traps were placed in the Forest Park Marjan (Split) on 196 ha of forest area. A pairs of pheromone preparations Pheroprax and Erosowit were compared, a system of three traps (Triplet) with a single flight barrier trap as well as the modified wet flight barrier trap with a regular flight barrier trap. In addition to the average number of catches in pheromone traps, particular attention was given to selectivity. Two predator species Tanasimus formicarius and Temnochila caerulea were found in traps, with T. formicarius in insignificant quantities relative to T. caerulea. The results indicate that Erosowit exhibits significantly higher catches compared to Pheroprax and is significantly more selective. Pheroprax has a very high catches of T. caerulea predators and is not recommended for practical use. The Triplet had only slightly better catches compared to the single flight barrier trap, but also showed slightly better selectivity. The Triplet did not show the expected effect due to the amount of the catch, which was slightly higher than in the single trap, but not significantly in order to recommend their use. The wet flight barrier trap turned out not to be satisfactory as it does not produce significantly higher catches than a regular flight barrier trap, and is twice less selective. Given the additional costs (trap adaptation, fluid that needs to be changed, slower collection), this trap type is not recommended for use. Comparing the results of the catch in 2019, the number of bark beetles was found to be almost 5 times lower than in 2018.

KEY WORDS: Pinus halepensis, Erosowit, Pheroprax, Taemnochila caerulea, Thanasimus formicarius, climate changes. 